Another curious piece of ritual, if Mr. Woolley's interpretation be accepted, is brought to light in a later building, which lay over the First Dynasty temple. Here were found four pits of some size - one rectangular pit is $15 \mathrm{ft}$. by $12 \mathrm{ft}$.- sunk in the floor. Three pits, one circular and two square, had been filled with clean red earth, the fourth rectangular pit had a layer of red earth superimposed on three layers of carefully laid gypsum blocks. Mr. Woolley offers the suggestion that these pits were intended for the foundations of altars, and aptly cites the "clean earth" which the old Sumerians brought for the foundations of their temples.

\section{Corpus of Egyptian Pottery}

Tentative proposals for the compilation of a complete corpus of Egyptian pottery, which were discussed at Cairo in 1931, have now taken practical shape. A scheme has been drawn up by a committee consisting of Mr. Guy Brunton, Dr. Junker of Vienna and Mr. O. H. Myers. Excavators are to be supplied with cards on one side of which a print or drawing of the pot is to be affixed, and on the other information relating to it is to be given under a number of heads. These slips, when completed, will be returned to the editor of the corpus, Mr. G. L. Harding, or, during his absence while excavating at Lachish, to Mr. O. H. Myers of the Egypt Exploration Society. The scheme of the corpus is based upon the "Predynastic Egyptian Corpus" issued by Sir Flinder. Petrie in 1921, as supplemented by the additional material obtained by Mr. Brunton in his Badarian excavations. It is, however, to be continued beyond these limits to the Arab period. The co-operation has been secured of the Egyptian Antiquities Service, the French, German and Italian institutes, the Egypt Exploration Society, the Oriental Institute of the University of Chicago and nearly all the other bodies represented in the archæological exploration of Egypt.

\section{An Experimental Air-Map}

WiTh the view of devising a suitable system of cartography for aviators the American Geographical Society has constructed an experimental sheet of the Pittsburgh-Cleveland area on a scale of $1: 500,000$, which is published in the Geographical Review for January 1933 with accompanying text by Mr. O. M. Miller. Since the drainage system is the most conspicuous guide to an airman, all water is shown in white against a background of grey, varying tints of which are used to show the surface relief. The darkest tint, contrary to custom, shows the lowest ground. White spot heights are at water-level and black spot heights at the highest points in any area. Conspicuous relief features, such as bold escarpments, are marked by black hachuring but this seems to be sparingly used. A general description of surface conditions has been attempted such as "farming country", "forested uplands", etc. Railways in black and roads in green stand out well. Red is used exclusively for objects dangerous to flying, including built-over areas, power transmission lines and oil tanks. Air ports, beacons and lighthouses are shown in yellow. Air ports are named in black, other place-names being in red. The projection used is the modified polyconical. Meridians and parallels and lines of magnetic declination are omitted from the main map and shown on a key map in the margin. The American Geographical Society invites criticisms of this sheet from aviators.

\section{Institute of Chemistry of Great Britain and Ireland}

Ar the fifty-fifth annual general meeting of the Institute of Chemistry held on March 1, the Meldola medal was presented to Dr. L. E. Sutton, of Oxford, and the Sir Edward Frankland medal and prize to Mr. L. Young, of the Royal College of Science. In moving the adoption of the report of Council, the president, Dr. G. C. Clayton, remarked on the increasing activity of the Institute. Dr. Clayton pointed out that for positions of control, science alone does not suffice: the chemist must acquire much knowledge and experience and become endowed with those not less-important qualities of character, judgment and tact, which responsibility entails. Not only competition, but also discovery and invention, together with modern methods in administration and management, have contributed to the existence of conditions which are bewildering to economists and financiers. These difficulties are not new : they were present when the mechanisation of industry started but have not become more acute. It is for chemists to put our old industries in the most favourable position to meet competition, and even more to branch out into new lines, especially new industries, which, by giving employment, will absorb some of those displaced by world competition in many of the heavy industries. Prof. J. F. Thorpe was elected president of the Institute in succession to Dr. Clayton.

\section{Recent Investigations in Nutrition}

The Minister of Health has directed the attention of county and county borough councils and other maternity and child welfare authorities to certain recent investigations and the recommendations of the Advisory Committee on Nutrition based on them (Circular 1290 : 1932 : H.M. Stationery Office. Price 2d. net). They deal with Dr. Helen Mackay's work on the nutritional anæmia of infancy, Prof. and Mrs. Mellanby's researches on the etiology of rickets and dental decay and Dr. Corry Mann's experiment on the effects of additional milk in the diet of schoolboys. For preventing nutritional anæmia, it is recommended that iron ammonium citrate should be added to the milk given to infants or that a dried milk containing added iron should be used. It is pointed out that severe rickets is rapidly disappearing in Great Britain, but that in some areas the milder form of the disease is still prevalent. Faulty dentition is widespread. The importance of the diet of pregnant and nursing mothers and of infants and young children containing a sufficient amount of calcium, phosphorus and vitamin $\mathrm{D}$ is therefore emphasised. Of these, vitamin $\mathrm{D}$ is the most likely to be deficient. The diet should contain fat fish such as herrings, 